
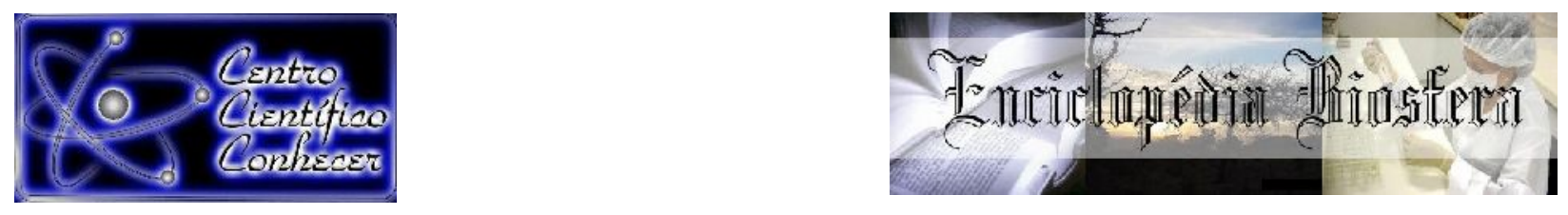

\title{
RELATION BETWEEN BOVINE MILK QUALITY, PRODUCTION VOLUME, AND ENVIRONMENTAL VARIABLES IN DAIRY FARMS
}

\author{
Flávio José Simioni ${ }^{1}$, Carolina Riviera Duarte Maluche Baretta ${ }^{2}$, Leandro \\ Samia Lopes ${ }^{3}$, Lenita Moura Stefani ${ }^{4}$, Tarcizo Tizziani ${ }^{5}$ \\ ${ }^{1}$ Professor Doutor da Universidade do Estado de Santa Catarina (UDESC), Centro de \\ Ciências Agroveterinárias (CAV), Lages-SC, Brasil \\ ${ }^{2}$ Professora Doutora Universidade Comunitária da Região de Chapecó \\ (UNOCHAPECÓ), Chapecó, SC - Brasil. E-mail: carolmaluche@unochapeco.edu.br \\ ${ }^{3}$ Professor Doutor da Universidade Federal de Minas Gerais (UFMG), Belo \\ Horizonte-MG, Brasil \\ ${ }^{4}$ Professora Doutora da Universidade do Estado de Santa Catarina (UDESC), Centro \\ de Educação Superior do Oeste (UDESC OESTE), Chapecó-SC, Brasil \\ ${ }^{5}$ Doutor, Coordenador Técnico Empresa Nutreminas - Ponta Nova, MG - Brasil
}

Recebido em: 06/04/2019 - Aprovado em: 10/06/2019 - Publicado em: 30/06/2019 DOI: 10.18677/EnciBio_2019A117

\begin{abstract}
The objective of this study was to evaluate the relation between dairy farms with different volumes of milk production ( $\mathrm{L}$ milk/day) and milk quality in the Western region of Santa Catarina State, as well as to identify environmental characteristics that could be associated with milk quality. Twenty-nine dairy farms were surveyed and categorized into three groups according to the volume of milk produced daily: S1, less than 200 L/day; S2, from 201 to 500 L/day; and S3, more than 500 L/day. Milk samples were collected from the bulk tank and analyzed for fat, protein, and lactose, somatic cell count (SCC), and total bacterial count (TBC). A questionnaire was applied to dairy farmers in order to obtain a set of twenty explanatory variables that may influence milk quality such as farmer profile, farm structure, and management. Outcome variables were evaluated by Principal Component Analysis (PCA) and Redundancy Analysis (RA). Low values of SCC, TBC and fat content were found to be strongly associated with greater volumes of production (S3). Type of milking and feeding program were the variables that most interfered with milk quality, followed by the average production per cow and type of grazing.
\end{abstract}

KEYWORDS: multivariate analysis, milk composition, total bacterial count.

\section{RELAÇÃO ENTRE ESCALA DE PRODUÇÃO, QUALIDADE DO LEITE E VARIÁVEIS AMBIENTAIS EM PROPRIEDADES LEITEIRAS}

\section{RESUMO}

Objetivou-se com este trabalho avaliar a relação entre diferentes escalas de produção e os parâmetros de qualidade do leite na região Oeste de Santa Catarina, e identificar variáveis ambientais que estivessem associadas à qualidade do leite. 
Foram avaliadas 29 propriedades leiteiras classificadas em três escalas de produção: S1, com produção de até $200 \mathrm{~L} /$ dia; S2, de 201 até $500 \mathrm{~L} /$ dia; e S3, com volume acima de $500 \mathrm{~L} / \mathrm{dia}$. As amostras de leite foram coletadas diretamente dos tanques de resfriamento para determinação dos teores de gordura, proteína, lactose, contagem de células somáticas (CCS) e contagem bacteriana total (CBT). Após a coleta, foi aplicado um questionário para a obtenção de um conjunto de vinte variáveis explicativas, que representassem as características relacionadas aos parâmetros de qualidade do leite, como o perfil do produtor, a estrutura da propriedade e as práticas de manejo adotadas. As variáveis foram avaliadas através da Análise de Componentes Principais (ACP) e Análise de Redundância (AR). Os resultados indicaram que os menores valores de CCS e CBT, bem como a redução dos teores de gordura estiveram fortemente associados à maior escala de produção (S3). O tipo de ordenha e o sistema de arraçoamento foram as variáveis que mais interferiram nos parâmetros de qualidade do leite, seguidas da produtividade média das vacas e do tipo de pastejo.

PALAVRAS-CHAVE: análise multivariada, composição do leite, contagem bacteriana total.

\section{INTRODUCTION}

Milk production in the state of Santa Catarina grew 3.8\% in 2016 compared with 2015, reaching 3.0 billion liters annually. The Western region has the largest milk production, accounting for $75.1 \%$ of the total milk produced in Santa Catarina (IBGE, 2017; ICEPA, 2017). According to the Agricultural Census of the Brazilian Institute of Geography and Statistics (IBGE, 2009), the number of dairy farms in Santa Catarina has decreased from 145 thousand in 1995/96 to approximately 89 thousand in 2006, while the number of cows milked has increased from 504 thousand to approximately 580 thousand in the same period. Despite the $60 \%$ decrease in the number of dairy farms, total milk production has increased from 869 million in 1995/96 to approximately 1.4 billion liters annually in 2006 , mainly due to improvements made in the production system.

The main feature of milk production in Western Santa Catarina is based on family farms, which mostly have areas up to 50 hectares, responsible for $75 \%$ of all milk produced in the state (ICEPA, 2017). Thus, the search for better milk quality could be a motivating factor in the region (NERO et al., 2009), especially in small properties more vulnerable to price fluctuations (BODENMULLER FILHO et al., 2010). Furthermore, advances regarding the minimum milk quality standards have recently been improved through the introduction of new regulation by the Federal Government (BRASIL, 2002; 2011). Dairy industries were encouraged to adopt premium payments based on milk quality and to improve their programs for good manufacturing practices. Due to a diversity of factors that can affect milk quality one may ask: what are the factors associated with farm size that might interfere with milk quality? A common association between larger farms and more intense use of technology and knowledge may exist.

Therefore, the aim of this study was to verify the relation between farm size and milk quality parameters, as well as to identify with multivariate techniques which environmental variables are associated with milk quality. 


\section{MATERIAL AND METHODS}

The experiment was conducted with a data set collected on different dairy farms of the Western part of Santa Catarina State from December 2010 and February 2011. Farms (29) were randomly selected in 12 municipalities from the West of Santa Catarina State, South of Brazil. From each farm, two raw milk samples were collected from the bulk tank or dip tanks, in a total of 58 samples. After homogenization in the tank, the milk collected was stored in $50-\mathrm{mL}$ vials containing Bronopol $\left({ }^{\circledR}\right.$ (2-bromo-2-nitropropane-1,3-diol) for centesimal analyses and SCC (INTERNATIONAL DAIRY FEDERATION, 1995, 1996), and in another flask with sterilized azidiol with preservative (sodium azide and chloramphenicol) for TBC. Milk samples were placed in an isothermal box with ice at a temperature of $4-8^{\circ} \mathrm{C}$ and sent to the laboratory of the State Center of Research and Diagnostics in Food (UNC/CIDASC, Concórdia/SC), accredited by the Brazilian Network for the Control of Milk Quality (RBQL), for physical-chemical and microbiological analyses.

Dairy farms were grouped using a questionnaire as a tool for data collection during a visit to the property. All dairy farms were classified according to their size, considering the volume of milk produced daily as follows: scale 1 (S1) with milk production up to $200 \mathrm{~L} /$ day, scale 2 (S2) from 201 to $500 \mathrm{~L} /$ day, and scale 3 (S3) volume above $500 \mathrm{~L} /$ day. Groups were evaluated under the following parameters of milk quality (response variables): fat (\%) (FAT), protein (\%) (PROT), lactose (\%) (LACT), somatic cell count (SCC) and total bacterial count (TBC).

The data were subjected to multivariate methods of statistical analysis in order to identify which explanatory variables contribute to the variability observed among groups, giving equal emphasis to all of them at once. The selection of explanatory variables was performed considering those that exert influence on the parameters of milk quality evaluated, considering farm data, dairy information, feeding and milking management, besides some other technical and economic indicators (Chart 1).

CHART 1 - Explanatory variables considered in the multivariate analysis

\begin{tabular}{|c|c|c|}
\hline Variable & Unit & Description \\
\hline TIME & year & Time that the farmer is working with dairy cattle \\
\hline COWS & units & Number of dairy cows in the property \\
\hline ANIM & units & Total number of dairy animals in the property \\
\hline PAST & ha & Area cultivated with annual pasture \\
\hline PERE & ha & Area cultivated with perennial pasture \\
\hline AREA & ha & Total area of the property \\
\hline MONE & R\$/year & Income from dairy (sales of animals, milk, and dairy products) \\
\hline PROD & L/cow/day & Average productivity from lactating cows \\
\hline WUM & units & Work unit man: one adult working full time \\
\hline FERT & yes/no & Use of chemical fertilizer on annual and perennial grassland \\
\hline ORGA & $\begin{array}{l}\text { how many } \\
\text { times }\end{array}$ & Applications of organic manure on pasture \\
\hline GRAZ & 1,2 & Type of grazing: 1- continuous; 2- rotational \\
\hline MILK & $1,2,3,4$ & $\begin{array}{l}\text { Milking system: } 1 \text { - by hand; } 2 \text { - mechanical with bucket; 3-mechanical } \\
\text { with a milk transfer; 4- mechanical totally closed }\end{array}$ \\
\hline WATE & yes/no & Use of hot water to wash milking equipment \\
\hline CONC & yes/no & Feed concentrate to cows according to their milk production \\
\hline POWE & $1,2,3,4$ & $\begin{array}{l}\text { Feeding system: } 1 \text { - pasture; } 2 \text { - pasture + silage; } 3 \text { - pasture + silage + } \\
\text { concentrate; } 4 \text { - pasture + silage + concentrate + hay }\end{array}$ \\
\hline
\end{tabular}




\begin{tabular}{|l|l|l|}
\hline FEED & $1,2,3,4$ & $\begin{array}{l}\text { Concentrate system: 1- does not provide concentrate; 2- provides the } \\
\text { same concentrate for all cows; 3- provides concentrate according to } \\
\text { the animal category; 4- provides concentrate according to the amount } \\
\text { of pasture }\end{array}$ \\
\hline FPER & Kg/day & Amount of feed per milking cow \\
\hline COLD & 1,2 & Type of refrigeration: 1- bulk; 2- immersion \\
\hline DAYS & $1,2,3$ & $\begin{array}{l}\text { Frequency of milk collection: 1- every day; 2- every other day; 3- every } \\
\text { three days }\end{array}$ \\
\hline
\end{tabular}

For multivariate analysis, the variables were used to obtain the length of the gradient in the model selection methodologyas described by Ter Braak and Smilauer (1998). Since this gradient was less than three (linear response), the Principal Component Analysis (PCA) was chosen. Associations between response variables and independent variables were also analyzed using a sorting technique, the Redundancy Analysis (RA), which was performed with the data processed in accordance with the equation: $x=\log (x+1)$. RA is a data sorting in which axes are designed to be linear combinations of the response variables.

Significance of correlation suggested by RA was obtained through the Spearman correlation coefficient. Initially, the analysis selected all explanatory variables for the model. Due to the lack of significance of permutation measured by Monte Carlo test, a Forward Selection was performed, and those variables with collinearity effect were eliminated and significant variables obtained by Marginal Effects and Conditional effects, such as TIME, MILK, FEED, PROD, GRAZ and FERT, were analyzed.

In addition, the data was subjected to univariate methods of statistical treatments and the means of the response variables compared to each other, using the Student t test for mean differences at the $5 \%$ level of significance, considering a design completely randomized. For variables that were not normally distributed, transformation log $(x)$ was applied. The univariate analyses were performed in the program Assistat (SILVA; AZEVEDO, 2016). Also, a set of environmental variables was also used in a complementary way to explain the data, which provided more details about the pattern of practices and production technologies used by each group.

\section{RESULTS AND DISCUSSION}

Multivariate analysis showed that dimension 1 (or principal component 1) of the PCA for scale of milk production explained $34.3 \%$ of the variability in the data, and dimensions 2, 3 and 4 explained $25.1,18.8$, and $12 \%$, respectively, totaling $90.2 \%$ of the total data variability. The eigenvalue for the first two dimensions were 0.343 and 0.251 , respectively. Dimensions 3 and 4 showed eigenvalues of 0.188 and 0.120 , respectively.

Since the percentage of response obtained by the first two dimensions explained $59.4 \%$ of the total variability of the accumulated data, this discussion was based on these two dimensions. Our results were similar to those obtained by Bodenmüller Filho et al. (2010), who gained $56.5 \%$ cumulative response in the first two dimensions to classify farms based on the characteristics of milk received by the industry in Londrina (Paraná State, Southern Brazil). Earlier studies by Aleixo et al. (2007) and Betancourt et al. (2005) obtained results below $50 \%$ of the variance from the accumulated sum of the dimensions 1,2 and 3 . 
Overall, arrangements of farm size were observed in separate quadrants (Figure 1), which represents the mean value of principal components represented through the centroids of treatments and there was clear separation between the three treatments. The biplot of the first two dimensions of PCA indicates the difference along the first axis, between S2 and S3, while S1 was separated from dimension 2.

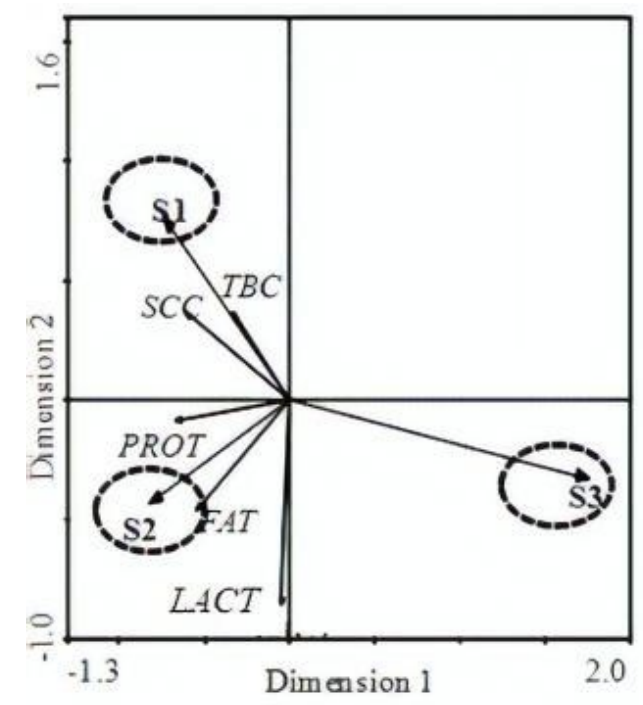

FIGURE 1 - Biplot of response variables (PROT, FAT, LACT, SCC and TBC)through Principal Component Analysis (PCA) in the plane defined as dimension 1 and 2, and the average value of main components represented through the centroids of groups. S1, S2 and S3 represent farm sizes: S1 - up to 200 liters, S2 - from 201 to 500 liters and, S3 - higher than 500 liters).

According to Figure 1, S2 is linked to increased fat, protein and lactose contents, while S1 is associated with higher values of SCC and TBC. On the other hand, S3 is associated with lower values of SCC and TBC. Dong et al. (2012) obtained similar results and found that biosecurity guidelines and good milking facilities were associated with lower levels of SCC. The authors also found that the size of the operation had little effect on SCC, although stricter hygiene found in larger farms favored better quality.

The resulting RA triplot clearly expresses the relation between milk quality parameters and selected variables (Figure 2). The eigenvalues based on milk quality parameters for RA axis in one, two and three, respectively, were $0.286,0.136$, and 0.041 (Figure 2). Among these, $57.7 \%$ are represented in dimension 1 and $27.4 \%$ in dimension 2. Together, these two dimensions explain $85.1 \%$ of the association between response and explanatory variables. Monte Carlo permutation test revealed a significant association between milk quality parameters and selected explanatory variables $(F=8833, p=0.006)$. 


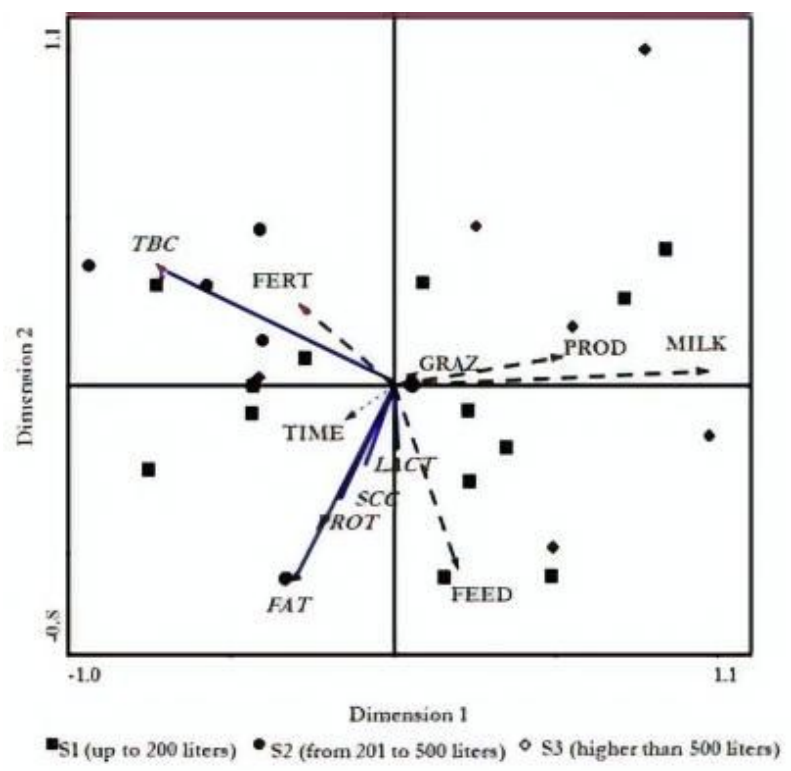

FIGURE 2 - Triplot of response variables (PROT, FAT, LACT, SCC and TBC) through Redundancy Analysis (RA) for farm size (S1, S2 and S3) and explanatory variables (GRAZ, TIME, PROD, MILK, FEED, FERT).

For this study, the variables selected (GRAZ, TIME, PROD, MILK and FEED) accounted for approximately $50 \%$ of the response of milk quality parameters evaluated, evidencing a significant correlation between milk quality and the explanatory variables.

Significant correlations were found for the type of milking (MILK) on axis 1 and feeding program (FEED) on axis 2, which accounts for most of the data variability regarding milk quality $(F=7.34 ; p=0.004$ and $F=3.14 ; p=0.028$, respectively), followed by grazing (GRAZ) and average yield (PROD) on axis 1 ( $F=2.52 ; p=0.068$ and $\mathrm{F}=2.45 ; \mathrm{p}=0.064$ ).

The type of milking influenced TBC (Figure 2). Vallin et al. (2009) analyzed milk samples of 19 cities in the center of Paraná State (Brazil) and observed that 14 out of 32 small farms with milking by hand $(43.8 \%)$ showed higher levels of TBC. On the other hand, Taffarel et al. (2013) reported lower TBC and, therefore, better microbiological milk quality when using channeled milking system and bulk milk cooler. Our results indicated that small-scale farms (S1) have higher TBC. This may be evident because these farms are less effective regarding milk management, being more reckless regarding hygienic practices. In addition, these farmers may not have the knowledge of good milking practices, or may insist on performing them improperly. The milk yield with high TBC is strikingly interesting from the points of view of public health and product shelf life.

Similar results to those of the present work were found by Werncke et al. (2016) in the South of Santa Catarina, where "properties with the most adequate infrastructure, greater adoption of the recommended practices of milking management, and more adequate feeding criteria produced milk with better quality."

Reduction in TBC is strongly associated with training and good management practices in dairy farms (BATTAGLINI et al., 2013; MARCONDES et al., 2014). Vallin et al. (2009) reported that the implementation of proper hygiene and milking management with efficient technical advice reduced TBC values by $87 \%$ on average. 
It was observed that only $1 / 3$ of the farmers from S1 group used detergent and hot water to clean the milking equipment. All other farmers from scale 2 and 3 groups used detergent, but $70 \%$ from S2 and 100\% from S3 used only hot water. The use of proper clothing and gloves is not adopted by farmers from $\mathrm{S} 1$, rarely used in scale 2 , and of little use by farmers from scale 3 . This set of practices may explain the differences in TBC found in this study.

There are many studies reporting that the use of concentrate to feed dairy cattle increases milk production (XIE et al., 2017). Alvim et al. (1999) studied strategies for feeding dairy cows and noticed that fixing the amount of concentrate in the first 90 days caused decrease $(P<0.05)$ in the curve of milk yield $(\mathrm{kg} / \mathrm{cow} /$ day $)$. On the other hand, varying the amount of concentrate according to the stage of lactation gave better stability to production, and increased peak of lactation. This explains the relation between FEED and higher levels of fat, protein, and lactose associated with the supply of concentrate. This also happens due to the fact that farmers with larger scale of production provide balanced nutrition for the animals when compared to farmers from S1 group.

The variable GRAZ is associated with higher levels of protein, fat, and lactose. This relation is probably due to increased use of rotational grazing system, allowing the growth of forage of better quality, with increasing digestibility. On the other hand, the higher use of chemical and organic fertilization on pasture of S2 and S3 farms were related to higher values of protein found in the milk.

Variables such as milking system (MILK=0.8564) and contribution to the average productivity $(\mathrm{PROD}=0.4597)$ were the ones that most contributed to the positive part of dimension 1, while the variable feeding program (FEED=-0.7001) was the largest contributor to the negative part of dimension 2.

Regardless of the scale of production, it became clear that protein levels in milk tended to have low variations. The increase in protein yield is caused by the increase in both protein content and milk yield (KHAN et al., 2015), but the potential to increase milk protein is relatively low, because the percentage varied only from $0.4 \%$ to $0.6 \%$. According to Sinclair et al. (2014), reducing dietary protein contents caused low impact on total milk protein yield and no effect on true milk protein yield, although efficiency in $\mathrm{N}$ use was improved. On the other hand, when diets with higher levels of protein are used, above animal's requirement, there is no change in the concentration of milk protein, but the non-protein nitrogen tends to increase.

There was no difference between treatments $(P>0.05)$ for fat, protein, lactose, and milk somatic cells (Chart 2) according to the univariate analysis (t test). Likewise, time in the activity did not differ between treatments, indicating that larger farms are not necessarily those with more time in the activity.

As expected, there were differences $(\mathrm{P}<0.05)$ in milk production between different scales of production, and S3>S2>S1 (Chart 2). However, the productivity (L/cow/day) did not differ between S1 and S2, and both were lower than S3. Therefore, farms with average daily production lower than $500 \mathrm{~L}$ of milk (S1 and S2) have less productive animals when compared to those with capacity exceeding $500 \mathrm{~L}$ (S3). These results are related to increased use of chemical fertilization and grazing as the type of feeding system (Chart 2), since these variables exert a strong influence on the quantity and quality of the diet consumed, enhancing animal productivity. 
CHART 2 - Mean values of response and explanatory variables according to farm size

\begin{tabular}{|c|c|c|c|}
\hline \multirow{2}{*}{ Variables } & \multicolumn{3}{|c|}{ Scale of production $(\mu \pm \sigma)$} \\
\hline & Scale 1 & Scale 2 & Scale 3 \\
\hline Fat (\%) & $3.87 a \pm 0.41$ & $3.53 a \pm 0.75$ & $3.31 a \pm 0.37$ \\
\hline Protein (\%) & $3.21 \mathrm{a} \pm 0.28$ & $3.23 a \pm 0.19$ & $3.09 \mathrm{a} \pm 0.15$ \\
\hline Lactose (\%) & $4.36 a \pm 0.10$ & $4.44 a \pm 0.15$ & $4.48 \mathrm{a} \pm 0.10$ \\
\hline $\begin{array}{l}\text { SCC (thousand } \\
\text { cells } / \mathrm{mL} \text { ) }\end{array}$ & $485.73 \mathrm{a} \pm 174.05$ & $574.77 \mathrm{a} \pm 334.47$ & $474.43 \mathrm{a} \pm 290.88$ \\
\hline $\begin{array}{l}\text { TBC (thousand } \\
\text { CFU/mL) }\end{array}$ & $602.56 \mathrm{a} \pm 605.59$ & $\begin{array}{ccc}421.84 & \text { ab } & \pm \\
840.63 & & \\
\end{array}$ & $128.00 b \pm 125.29$ \\
\hline Production (L/day) & $111.67 c \pm 43.80$ & $311.15 \mathrm{~b} \pm 85.52$ & $804.29 \mathrm{a} \pm 374.78$ \\
\hline $\begin{array}{l}\text { Time in the activity } \\
\text { (years) }\end{array}$ & $10.89 a \pm 8.45$ & $15.54 \mathrm{a} \pm 9.57$ & $14.71 \mathrm{a} \pm 8.58$ \\
\hline $\begin{array}{l}\text { Productivity } \\
\text { (L/cow/day) }\end{array}$ & $11.74 b \pm 3.67$ & $14.15 b \pm 2.64$ & $19.46 \mathrm{a} \pm 3.51$ \\
\hline $\begin{array}{l}\text { Chemical } \\
\text { fertilization (\%) }\end{array}$ & 44.40 & 69.20 & 85.70 \\
\hline Type of grazing & $\begin{array}{l}\text { Primitive: essentially } \\
\text { discontinuous }\end{array}$ & $\begin{array}{ll}\text { Primitive: } & \text { mixed } \\
\text { discontinuous } & \text { with } \\
\text { rotated } & \end{array}$ & $\begin{array}{l}\text { Essentially rotated } \\
\text { and well defined }\end{array}$ \\
\hline Type of milking & $\begin{array}{l}0 \% \text { mechanical } \\
\text { totally closed }\end{array}$ & $\begin{array}{l}46.15 \% \text { mechanical } \\
\text { totally closed }\end{array}$ & $\begin{array}{l}85.71 \% \text { mechanical } \\
\text { totally closed }\end{array}$ \\
\hline $\begin{array}{l}\text { Feeding } \\
\text { concentrate } \\
\text { program }\end{array}$ & Same for all animals & $\begin{array}{l}\text { According } \\
\text { categories }\end{array}$ & $\begin{array}{l}\text { According to milk } \\
\text { oproduction, } \\
\text { differentiating } \\
\text { categories }\end{array}$ \\
\hline
\end{tabular}

Note: Means followed by the same letter are not significantly different by Least Square Difference (LSD) $(\mathrm{P}<0.05)$

Farms with lower volumes of milk $(S 1)$ showed higher TBC $(P<0.05)$ than those with larger scale of production (S3), and S2 did not differ strongly. The total microbial population of raw milk is closely related to the contamination of the mammary gland and the external environment (ceilings and equipment), as well as storage conditions (temperature and time). There was no significant difference $(P>0.05)$ in SCC, indicating similar microbial contamination of the mammary gland between treatments, while TBC differed only between groups S1 and S3 (Chart 2). It is believed that the highest TBC values in group S1 are due to the lack of hygiene during milking and/or inadequate storage conditions. The lower values of TBC for group S3 can be explained by the greater frequency of use of the closed milking system for group S3, a fact that may reduce the contamination.

In Paraná, Belli et al. (2017) found higher fat content and TBC in small farms (up to $6000 \mathrm{~L} /$ month). TBC was also higher when the milking system was manual or with "bucket to the foot" using the cooling system by immersion and employed family labor with occasional technical assistance. The authors also found significant differences in TBC when comparing different practices of milking hygiene, milking equipment, and teat cleaning. Nutritional aspects that promote increased production, especially when in large scale, resulted in a lower percentage of milk fat. Freitas et al. (2017) found higher percentage of fat and SCC in animals with lower milk yield (5-15 $\mathrm{kg}$ day) when compared to the group of higher productivity (over $30 \mathrm{~kg} \mathrm{day}^{-1}$ ). Similar 
results were also found by Roza et al. (2015) when comparing properties with a low technological standard compared to medium- and high-technology groups.

According to the study of Rodrigues et al. (2005) with 180 dairy farms participating in the milk quality improvement program, management practices and bulk milk SCC were strongly associated with herd size and facility type. The authors showed that managers of freestall farms adopted more standardized procedures and recommended management practices compared to managers of herds housed in stall barns, showing lower SCC, greater milk yields, lower prevalence of subclinical mastitis and reduced incidence of clinical mastitis, resulting in fewer financial losses related to mastitis.

When studying the quality of milk, Baggio and Montanhini (2017) found that $34.7 \%$ of the samples showed at least one requirement in disagreement with the current milk quality legislation, and SCC was the most common parameter exceeding the maximum limit allowed. According to Botaro et al. (2013), the adoption of payment programs based on milk quality contributed to the reduction of SCC and TBC in cooperatives of Southeastern Brazil.

It was noticed that the improvement in milk production technologies demands more productive animals with greater nutritional requirements. In order to achieve higher levels of production it is essential to use concentrate, otherwise alterations in the concentration of fat could be observed.

\section{CONCLUSIONS}

It is possible to conclude that increased scale of production was associated with milk composition, leading to reduced levels of SCC and TBC. There was correlation between milk quality and the selected explanatory variables. The explanatory variables associated with feeding and milking management at different levels of milk production were the most related to the parameters of milk quality.

The application of multivariate statistical method allowed the previous selection of variables that helped point out differences between the three farm sizes. However, it is necessary to expand the study by adding a new set of variables already selected for the model, allowing further understanding of factors that may help farmers to improve milk quality.

\section{REFERENCES}

ALEIXO, S.S.; SOUZA, J.G.; FERRAUDO, A.S. Técnicas de análise multivariada na determinação de grupos homogêneos de produtores de leite. Revista Brasileira de Zootecnia, v.36, n.6, p.2168-2175, nov./dez. 2007. Disponível em: <http://www.scielo.br/scielo.php?pid=S1516-35982007000900029\&script=sci_arttext >. doi: 10.1590/S1516-35982007000900029

ALVIM, M.J.; VERNEQUE, R.S.; VILELA, D.; CÓSER, A.C.; BOTREL, M.A. et al. Estratégia de fornecimento de concentrado para vacas da raça holandesa em pastagem de coast-cross. Pesquisa Agropecuária Brasileira, v.34, n.9, p.1711-1720, $\quad$ set. $1999 . \quad$ Disponível em: <http://www.scielo.br/pdf/pab/v34n9/7624.pdf>. Acesso em: 18 dez. 2017.

BAGGIO, A.P.; MONTANHINI, M.T.M. Qualidade de leite cru produzido na região do Norte Pioneiro do Paraná. Revista Brasileira de Higiene e Sanidade Animal, v.11, 
n.2, p. 184-189, 2017. Disponível em: $<$ http://www.higieneanimal.ufc.br/seer/index.php/higieneanimal/article/view/393/2167 >. Acesso em: 15 nov. 2017.

BATTAGLINI, A.P.P.; FAGNANI, R.; DUNGA, K.S.; BELOTI, V. Difusão de boas práticas e caracterização de propriedades leiteiras. Archivos de Zootecnia, v.62, n.237, p.151-154, 2013. Disponível em: <http://dx.doi.org/10.4321/S0004-05922013000100017>. doi: $10.4321 /$ S0004-05922013000100017

BELLI, C.Z.P.; CULLMANN, J.R.; ZIECH, M.F.; MENEZES, L.F.G. DE; KUSS, F. Qualidade do leite cru refrigerado obtido em unidades produtivas no Sudoeste do Paraná. Revista de Ciências Agroveterinárias, v.16, n.2, p.109-120, 2017. Disponível em: <http://dx.doi.org/10.5965/223811711622017109>. doi: $10.5965 / 223811711622017109$

BETANCOURT, K.; IBRAHIM, M.; VILLANUEVA, C.; VARGAS, B. Caracterización del manejo productivo de sistemas lecheros en La cuenca del río Bulbul de Matiguás, Matagalpa, Nicaragua. Livestock Research for Rural Development, v.17, n.7, jul. 2005. Disponível em: <http://www.Irrd.org//rrd17/7/beta17080.htm>. Acesso em: 10 dez. 2018.

BODENMÜLLER FILHO, A.; DAMASCENO, J.C.; PREVIDELLI, I.T.S.; SANTANA, R.G.; RAMOS, C.E. et al. Tipologia de sistemas de produção baseada nas características do leite. Revista Brasileira de Zootecnia, v.39, n.8, p.1832-1839, 2010. Disponível em: <http://www.scielo.br/pdf/rbz/v39n8/v39n8a28.pdf>. Acesso em: 20 ago. 2017.

BOTARO, B.G.; GAMEIRO, A.H.; SANTOS, M.V.DOS. Quality based payment program and milk quality in dairy cooperatives of Southern Brazil: an econometric analysis. Scientia Agricola, v.70, n.1, p.21-26, 2013. Disponível em: <http://dx.doi.org/10.1590/S0103-90162013000100004>. doi: 10.1590/S0103-90162013000100004

BRASIL. Ministério da Agricultura Pecuária e Abastecimento. Instrução Normativa № 51, de 18 de setembro de 2002. Diário Oficial da União, de 20 de setembro de 2002, Seção 1, p.13. 2002. Disponível em: $<$ http://www.in.gov.br/visualiza/index.jsp?jornal=1 \&pagina=1\&data=20/09/2002>. Acesso em: 20 dez. 2017.

BRASIL. Ministério da Agricultura Pecuária e Abastecimento. Instrução Normativa № 62, de 29 de dezembro de 2011. Diário Oficial da União, de 30 de dezembro de 2011, Seção 1, p. 6. 2011. Disponível em: <http://www.in.gov.br/visualiza/index.jsp?jornal=1 \&pagina=1\&data=30/12/2011>. Acesso em: 12 Jan. 2018.

DONG, F.; HENNESSY, D.A.; JENSEN, H.H. Factors determining milk quality and implications for production structure under somatic cell count standard modification. 
Journal of Dairy Science, v.95, n.11, p.6421-6435, 2012. Disponível em: <http://dx.doi.org/10.3168/jds.2012-5522>. doi: 10.3168/jds.2012-5522

FREITAS, J.A. DE; SILVA, J.DA; GARCEZ NETO, A.F.; SANTOS, T.M.DOS. Somatic cell count and milk yield on physicochemical components of milk from free-stall housed cows. Semina: Ciências Agrárias, v.38, n.2, p.909-918, 2017. Disponível em: <http://dx.doi.org/10.5433/1679-0359.2017v38n2p909>. doi: 10.5433/1679-0359.2017v38n2p909

IBGE. Instituto Brasileiro de Geografia e Estatística. Pesquisa da Pecuária Municipal. $20176 . \quad$ Disponível em: $<$ https://cidades.ibge.gov.br/brasil/sc/pesquisa/18/0?ano=2017>. Acesso em: 24 Ago. 2018.

IBGE. Instituto Brasileiro de Geografia e Estatística. Censo Agropecuário 2006. Agricultura Familiar, primeiros resultados. Brasil, Grandes Regiões e Unidades da Federação. Brasília: MPOG, 2009.

Disponível em: $<$ https://biblioteca.ibge.gov.br/visualizacao/periodicos/50/agro_2006_agricultura_fami liar.pdf>. Acesso em: 24 Ago. 2018.

ICEPA. Instituto de Planejamento e Economia Agrícola de Santa Catarina. Centro de Socioeconomia e Planejamento Agrícola - Epagri/Cepa. Síntese Anual da Agricultura de Santa Catarina 2016-2017. 2017. Disponível em: < http://docweb.epagri.sc.gov.br/website_cepa/publicacoes/Sintese_2016_17_site.pdf >. Acesso em: 24 Nov. 2018.

IDF. International Dairy Federation. Whole milk - determination of milk fat, protein and lactose content: guidance on the operation of mid-infrared instruments. Brussels: IDF, 1996. 12p. (IDF Standard 141B).

IDF. International Dairy Federation. Milk - enumeration of somatic cells. Brussels: IDF, 1995. 8p. (IDF Standard 148A).

KHAN, N.A.; YU, P.; ALI, M.; CONE, J.W.; HENDRIKS, W.H. Nutritive value of maize silage in relation to dairy cow performance and milk quality. Journal of the Science of Food and Agriculture, v.95, n.2, p.238-352, 2015. Disponível em: <http://dx.doi.org/10.1002/jsfa.6703>. doi: 10.1002/jsfa.6703

NERO, L.A.; VIÇOSA, G.N.; PEREIRA, F.E.V. Qualidade microbiológica do leite determinada por características de produção. Ciência e Tecnologia Alimentar, v.29, n.2, p.386-390, abr./jun. 2009. Disponível em: <http://www.scielo.br/pdf/cta/v29n2/24.pdf>. Acesso em: 15 Fev. 2018.

MARCONDES, M.I.; JÁCOME, D.C.; SILVA, A.L.; RENNÓ, L.N.; PIRES, A.C.S. Evaluation of raw milk quality in different production systems and periods of the year. Revista Brasileira de Zootecnia, v.43, n.3, p.670-676, 2014. Disponível em: <http://dx.doi.org/10.1590/S1516-35982014001200007>. doi: $10.1590 /$ S1516-35982014001200007 
RODRIGUES, A.C.O.; CARAVIELLO, D.Z.; RUEGG, P.L. Management of Wisconsin dairy herds enrolled in milk quality teams. Journal of Dairy Science, v.88, n.7, p.2660-2671, 2005.2 Disponível em: <https://doi.org/10.3168/jds.S0022-0302(05)72943-X>. doi: 10.3168/jds.S0022-0302(05)72943-X

ROZA, L.F.; LOPES, L.S.; SIMIONI, F.J.; DA SILVA, A.S.; SCHONELL, E.P. et al. Milk quality of properties with different technological standards. Biosciense Journal, v.31, n.6, p.1760-1770, $2015 . \quad$ Disponível em: <http://dx.doi.org/10.14393/BJ-v31n6a2015-26340>. doi: 10.14393/BJ-v31n6a2015-26340

SILVA, F.de A.S.; AZEVEDO, C.A.V.de. The assistat software version 7.7 and its use in the analysis of experimental data. African Journal of Agriculture Research, v.11, n.39, p.3733-3740, 2016. Disponível em: <http://dx.doi.org/10.5897/AJAR2016.11522>. doi: 10.5897/AJAR2016.11522

SINCLAIR, K.D.; GARNSWORTHY, P.C.; MANN, G.E.; SINCLAIR, L. A. Reducing dietary protein in dairy cow diets: implications for nitrogen utilization, milk production, welfare and fertility. Animal, v.8, n.2. p.262-274, 2014. Disponível em: <http://dx.doi.org/10.1017/S1751731113002139>. doi: 10.1017/S1751731113002139

TAFFAREL, L.E.; COSTA, P.B.; OLIVEIRA, N.T.E.; BRAGA, G.C.; ZONIN, W.J. Contagem bacteriana total do leite de diferentes sistemas de ordenha e resfriamento. Arquivos do Instituto Biológico, v.80, n.1, p.7-11, 2013. Disponível em: <http://dx.doi.org/10.1590/S1808-16572013000100002>. doi: 10.1590/S1808-16572013000100002

TER BRAAK, C.J.F.; SMILAEUR, P.C. Reference manual and user's guide to canoco for windows: software for canonical community ordination (version 4). Ithaca: Microcomputer Power. 1998. 252p.

VALLIN, V.M.; VANERLI, B.; BATTAGLINI, A.P.; TAMANINI, R.; FAGNANI, R. et al. Melhoria da qualidade do leite a partir da implantação de boas práticas de higiene na ordenha em 19 municípios da região central do Paraná. Semina: Ciências Agrárias, v.30, v.1, p.81-188, 2009. Disponível em: <http://dx.doi.org/10.5433/1679-0359.2009v30n1p181>. doi: 10.5433/1679-0359.2009v30n1p181

WERNCKE, D.; GABBI, A. M.; ABREU, A. S.; FELIPUS, N. C.; MACHADO, N. L. et al. Qualidade do leite e perfil das propriedades leiteiras no Sul de Santa Catarina: abordagem multivariada. Arquivo Brasileiro de Medicina Veterinária e Zootecnia, v.68, n.2, p.506-516, 2016. Disponível em: < http://dx.doi.org/10.1590/1678-4162-8396>. doi: 10.1590/1678-4162-8396

XIE, Z.L.; ZHANG, J , ZHANG, D. M.; LI, J. F.; LIN. Y. H. Effect of a high-concentrate diet on milk components and mammary health in Holstein dairy cows. Genetics and Molecular Research, v.16, n.1, p.1-10, 2017. Disponível em: <https://www.geneticsmr.org/articles/effect-of-a-highconcentrate-diet-on-milk-compon ents-and-mammary-health-in-holstein-dairy-cows.pdf>. Acesso em: 06 Jan. 2019. 